\title{
Determination of the use of whey and propolis on some growth characteristics, on blood values and diarhea of the goat kids
}

Selda MANAV

Adnan Menderes University: Adnan Menderes Universitesi

Murat YILMAZ ( $\sim$ myilmaz@adu.edu.tr)

Adnan Menderes University Agriculture Faculty

Research Article

Keywords: Goat Kids, Whey, Propolis, Growth Characteristics, Blood Values, Diarrhea

Posted Date: November 22nd, 2021

DOI: https://doi.org/10.21203/rs.3.rs-1036184/v1

License: (c) (i) This work is licensed under a Creative Commons Attribution 4.0 International License. Read Full License 


\section{Abstract}

This study was conducted to obtain an alternative more economical and healthier milk substitute feed by adding whey powder and propolis to cow's milk in goat kid rearing. 40 Saanen goat kids born in the same period and were divided into 4 groups 7 days after thei birth. The kids were divided into 4 groups 10 by 10 into control group (CG) who were kept together with their mothers and into experimental groups 1-2-3 (EG1,EG2, EG3) who were kept in seperate sections. Kids in all three experimental groups were fed only with the formula (cow milk+whey powder+water). In the EG2 and EG3, the kids were given $0.4 \mathrm{cc}$ and $0.2 \mathrm{cc}$ propolis respectively in addiditon of the formula once a day. Some growth and development parameters and rectal temperatures of the kids were measured once a week and morning and evening diarrhea scorings were taken in all groups. Some biochemical and hematological analyzes were performed. According to all the results obtained, the differences in the body temperatures and in the glucose and urea values among the groups were found to be significant and the other characteristics were statistically significant $(P<0.05)$. The insignificant difference between the average growth and development parameters of the kids in the CGs in the CG was an important finding in growing kids more economically and reserving the goat milk for more profitable procedures. According to the diarrhea scores, it was observed that propolis was effective on diarrhea and it was concluded that it could be used in growing kids as a preventive measure. Feeding kids with the formula was found more economical than feeding them with mother-milk. As a result of this study, it could be suggested that the use of milk replacers containing whey and propolis will positively affect the growth, the development and the health of the goat's kids.

\section{Introduction}

Artificial milk feeding is used in sheep and goat farms depending on the increase in the amount of marketable milk. Due to the high prices of goat milk, various food formulations have been tried in artificial applications. Cow milk and whey powder were used as a milk substitute feed for lamb and calf feeding because of its low cost and easy supply. Gailna et al (1995) fed different genotype goat kids with cow's milk and different proportions (20-35-50\%) of whey and found that the live weights were statistically similar to those of offsprings sucking their mothers.

Mortality in the pre-weaning periods of goat kids is a major problem. After birth, the process of formation of active immune elements begins in the offsprings. Depending on the environmental conditions in this process and on the adaptation ability of the animal, it is observed that the offspring with low resistance die in the first month (Karslı and Evci 2018). In the studies conducted, the mortality rates of the goat kids vary between 2,2-14\% in the first 5 days after birth and this rate increases more on the 10th day and lateron (Holmøy and Waage 2015; Ünal et al. 2018). During this adaptation period after birth, antibiotics were used in the past to prevent the mortality rate of the offspring and this use was prohibited due to the increase of pathogen resistance. The search for using alternative feed additives against the negative effects of intestinal pathogens instead of antibiotics has increased in breeding the offsprings with or without mother. For this purpose, probiotics, prebiotics, organic acids and essential oils have recenltly been used commercially(Ünlü et al. 2013; Zeng et al. 2015).

Propolis is an effective bee product in the formation of an aseptic environment in the hive due to its antimicrobial activity. It is collected by bees from various parts of plants and used for different purposes in the hive (Bonamigo et al. 2017; Kocot et al. 2018). It is known that propolis is effective on various bacteria (Velikova et al. 2000; Katırcıoğlu and Mercan, 2006), viruses (Kujumgiev et al. 1999; Harish et al. 1997), fungi (Murad et al., 2002) and molds (Silici et al., 2005; Kujumgiev et al. 1999). In addition, it has been determined that propolis has an immunomodulatory effect on mammals (Freitas et al. 2011; Onur et al. 2018). There are many studies on its effects on poultry (Denli et al. 2005; Tekeli et al. 2011; Hašèík et al. 2012; Aygun and Sert 2013). In ruminants, many studies have been conducted to determine the effects of propolis on rumen digestive metabolism and reproduction (Kupczyński et al. 2012; Zeedan and Komonna, 2013;Kara et al. 2014). Propolis supplementation creates significant differences in some hematological values in Hanwoo calves (Yang et al. 2010). Zeedan and Komonna (2013) found that propolis supplementation to buffalo cows positively affected feed utilization, reproductive performance, milk yield, offspring birth weight and offspring immunity. In addition, it has been determined that the addition of propolis extract to calves as an anti-diarrhea agent reduced diarrhea symptoms in calves and increased live weight (Chudoba et al (2003). Propolis supplementation improved efficiency, oxidative status and immune response in barki sheep and lambs (Shedeed et al. 2019). In addition, it was determined that propolis supplementation increased body weight in Ivesi sheep (Al-Khafajı 2016). Knowing the physiological reference values of blood in goat kids is important in terms of providing useful information for recognizing the animal's adaptation mechanisms against the environment during the first month of their lives and for diagnosing the diseases to be experienced (Zumbo et al. 2011). In sheep and goat breeding, the emergence of self-immunity of new born kids and lambs and their adaptation to the environment happen during a critical period that could lead to severe kid and lamb losses. In this period, knowing certainage related hematological reference intervals of lambs and goats helps to evaluate their care, their nutrition and their health status in a realistic way (Abdolvahabi et al. 2018). It is also known that age has serious effects on hematological values (Abdolvahabi et al. 2018). Although there are a lot of studies on hematological values of most farm animals, there are few studies on goat-kid hematology and there are very few studies on age-related hematological changes in Saanen goats on the basis of breed (Zumbo et al. 2011; Abdolvahabi et al. 2018).

The aim of this study was to investigate an alternative, more economical and preferable milk substitute feed by adding whey to cow's milk and to determine the effect of propolis supplementation on some growth development parameters and blood values of goats.

\section{Materials And Methods}


This study was carried out in the Goat Breeding Unit of Aydın Adnan Menderes University Faculty of Agriculture Animal Research and Application Center. The coordinates of the enterprise are $37^{\circ} 45^{\prime} 03.31^{\prime}$ ' $\mathrm{N}$ and $27^{\circ} 45^{\prime} 27.16^{\prime}$ ' $\mathrm{E}, 52 \mathrm{~m}$ above sea level. Mediterranean climate prevails in the region. Environmental temperature and humidity measurement was determined by a Hobo device, daily ambient temperature $\left({ }^{\circ} \mathrm{C}\right)$, and relative humidity $(\mathrm{RH}, \%)$. The mean temperature-humidity index $(\mathrm{THI})$ was calculated according to equation: $\left\{(0.31-0.31 \mathrm{RH} / 100)\left(\mathrm{db}{ }^{\circ} \mathrm{C}-14.4\right)\right\}(\mathrm{Marai}$ vd. 2007$)$.

The animal material of the study consisted of 40 kids born in the same period of 40 synchronized goats. 40 Goats kids were divided into four groups: Control Group-CG $(n=10)$ was kept free with their mothers and freely sucked their mothers. The first experimental group kids-EG1- $(n=10)$ were fed only with the formula ( $75 \%$ cow's milk $+10 \%$ whey powder $+15 \%$ water), the second expermental group kids-EG2-were given the formula and 0.4 cc propolis and the third experimental group kids-EG3-were given the formula and $0.2 \mathrm{cc}$ propolis.

The kids in the control group stayed together with their mothers in a semi-open shelter of about 30 square meters and sucked their mothers freely. The mothers of the kids in the control group were not milked during the trial. The kids in the EG1,EG2 and EG3 were separated from their mothers and placed in $1.5 \times 1.5 \mathrm{~m}$ semi-open individual chambers. The kids in all experimental groups were bottle fed individually twice a day with the formula at body-temperature made by mixing $75 \%$ cow's milk $+10 \%$ whey powder $+15 \%$ water. Lactopro brand whey (oil $<1$. $5 \%$, lactose $>5 \%$, protein $7-10 \%$, lactic acid $<15 \%$, Ph $6-6.2 \%$, salt $<2.20 \%$, Ash $<5 \%$, solubility $98 \%$, moisture $<2 \%$ ) used in milk substitute feed. The amount of the formula given to the kids was equal to the $10 \%$ of the live weight of every kid and it was increased in parallel with the live weight increase. In addition, 0.4 and 0.2 cc ethanolic propolis extract was given orally to the kids in the EG2 and EG3 respectively once a day with an injector. Propolis extracts were obtained from the company named İdapolis from Canakkale 18 Mart University Technopark. The foods consumed daily were noted for each kid. After the third week of the experiment, $100 \mathrm{~g}$ of good quality dried clover was placed in front of each animal. During the 4 th week, $100 \mathrm{~g}$ starter feed containing $20 \%$ crude protein and $2700 \mathrm{kcal} / \mathrm{kg}$ metabolic energy was placed in front of each animal. In order to determine the feed consumption of the kids, the remaining feeds during the 3rd and 4th weeks were weighed and recorded weekly. The amount of feed was increased in a controlled manner due to the increase in live weight. In the study, clean water was kept in front of the kids starting from their second week.

Live Weights, BCS,body measurements and diarrhea scoring(DS)

The kids were weighed individually every week from birth and their live weight(LW) were determined. The kids were kept hungry from morning before weighing. Body condition score (BCS) was recorded after weighing. (Russell et al. 1969). Body length(BL), height of withers(HW), chest circumference(CC) measuring were taken by stick and tape measure on a flat concrete floor. The rectal body temperature of the kids was measured every week with a digital thermometer. The daily health conditions of the animals were observed every day. Stools were checked twice a day, in the morning and evening, and diarrhea scores was performed using the stool consistency scaling system. The scoring ranges between 1 and 4 ( $1=$ watery; 2 = fluid; 3 = soft; 4 = normal) (Ayışığı et al. 2005).

.Blood sampling and hematological analysis

Blood samples were taken from animals in all groups totally three times throughout the study, on the first day when the goat kids were grouped, in the middle of the experiment and at the end of the experiment. Blood samples were taken from the jugular veins of the neck (vena jugularis), approximately $10 \mathrm{ml}$ and were put into EDTA tubes (ethylenediamine tetra acetic acid) for hematological analysis and into heparin tubes for biochemical analysis. Hemogram values were analyzed using Horiba Medical ABX Micros ABX brand device.

\section{Statistical Analysis}

Statistical analysis of the features specified in the study was performed using the linear mixed model equation defined below. $y_{i j k l}=\mu+\alpha_{i}+\tau_{j}+(\alpha \tau)_{i j}+\delta_{k}+e_{i j k l} y_{i j k l}$. i. in the group, j. day and the observation value of the k. individual of gender I. in terms of the analyzed feature, $\mu$;Overall mean, $\alpha_{i}$ : I. the effect of the group (i: EG1, EG2, EG3 and CG), $\tau_{j}$; j. effect of the day $(\mathrm{j}: 1,8,14,21,30,37),(\alpha \tau)_{i j}$ : group and day interaction, $\delta_{k}: k$ influence of gender (k: Male and Female) and $e_{i j k l}$. Random error term). The mixed model equation described above was applied to the analysis of the data using the nlme (Linear and Nonlinear Mixed Effects Models) package (Pinheiro et al. 2013) defined in the R-packet (R Core Team) program with $\Omega$ variance-covariance error matrix. Unstructured variance-covariance structure was determined using Schwarz's Bayesian Criterion (Littell et al. 1997). After the variance and covariances in the $\Omega_{-}$i matrix were estimated by the maximum likelihood method, whether the factors in the linear mixed model equation were statistically significant was determined by the F-test. The significance of the differences between the levels of statistically significant factors was determined by applying the Tukey test at the $p<0.05$ significance level.

\section{Results}

Climatic and Geographical Conditions

The place where the experiment was conducted is $52 \mathrm{~m}$ above sea level and in a region with a Mediterranean climate and the temperature difference between day and night is high. During the experiment, the lowest temperature was $1^{\circ} \mathrm{C}$ and the highest temperature was $27^{\circ} \mathrm{C}$. The average humidity varied between 57 and 68\%. Temperature humidity index was found to be between 10.58 and 16.72 . 
There was no difference between the groups in terms of live weight (LW) during the experiment period. The fact that there was no statistical difference in body weight gains between the CG and the other 3 EGs was an important result since it proved that animals could gain similar body weight with the formula feed (Table 1).

Among groups for BCS, in the third and fourth measurements, the difference between EG3 and CG was found to be statistically significant ( $<<0.05)$. When we evaluated the groups within themselves, the difference between the means was found to be insignificant in all groups except the control group.

Table 1

Least squares means and standard errors of the kids' LW, BCS, BL, WH and CC

\begin{tabular}{|c|c|c|c|c|c|c|c|c|}
\hline \multirow[t]{6}{*}{ LW } & & 1st day & 8th day & 15 th day & 22 th day & 29 th day & 36 th day & $\mathrm{P}$ \\
\hline & EG1 & $4.59 \pm 0.36^{a}$ & $4.92 \pm 0.41^{a}$ & $5.5 \pm 0.47^{b}$ & $6.43 \pm 0.52^{c}$ & $7.58 \pm 0.59^{d}$ & \multirow{2}{*}{$\begin{array}{l}8.68 \pm 0.61^{\mathrm{e}} \\
8.71 \pm 0.61^{\mathrm{e}}\end{array}$} & \multirow{2}{*}{ * } \\
\hline & EG2 & $4.62 \pm 0.36^{a}$ & $4.89 \pm 0.41^{a}$ & $5.45 \pm 0.47^{b}$ & $6.36 \pm 0.52^{c}$ & $7.67 \pm 0.59^{d}$ & & \\
\hline & EG3 & $4.57 \pm 0.36^{a}$ & $4.81 \pm 0.41^{a}$ & $5.46 \pm 0.47^{b}$ & $6.43 \pm 0.52^{c}$ & $7.66 \pm 0.60 \mathrm{~d}$ & $8.67 \pm 0.62 \mathrm{e}$ & * \\
\hline & CG & $4.57 \pm 0.36^{a}$ & $5.62 \pm 0.41^{b}$ & $6.97 \pm 0.47^{c}$ & $8.17 \pm 0.52^{d}$ & $9.32 \pm 0.59^{e}$ & $9.86 \pm 0.61^{f}$ & * \\
\hline & $P$ & IN & IN & IN & IN & IN & IN & \\
\hline \multirow[t]{5}{*}{ BCS } & EG1 & $1.74 \pm 0.09^{a}$ & $1.72 \pm 0.09^{a}$ & $1.92 \pm 0.14^{\mathrm{aAB}}$ & $1.87 \pm 0.12^{\mathrm{aAB}}$ & $1.67 \pm 0.10^{a}$ & $1.74 \pm 0.08^{a}$ & IN \\
\hline & EG2 & $1.79 \pm 0.09^{a}$ & $1.79 \pm 0.09^{a}$ & $1.94 \pm 0.14^{\mathrm{aAB}}$ & $1.92 \pm 0.12^{\mathrm{aAB}}$ & $1.97 \pm 0.10^{a}$ & $1.84 \pm 0.08^{a}$ & IN \\
\hline & EG3 & $1.69 \pm 0.09^{a}$ & $1.74 \pm 0.09^{a}$ & $1.83 \pm 0.14^{\mathrm{aA}}$ & $1.72 \pm 0.12^{\mathrm{aA}}$ & $1.91 \pm 0.10^{a}$ & $1.74 \pm 0.09^{a}$ & IN \\
\hline & CG & $1.87 \pm 0.09^{a c}$ & $2.04 \pm 0.09^{\mathrm{ad}}$ & $2.37 \pm 0.14^{\mathrm{bB}}$ & $2.24 \pm 0.12^{\mathrm{bB}}$ & $1.94 \pm 0.10^{\mathrm{ad}}$ & $1.67 \pm 0.08^{c}$ & * \\
\hline & $P$ & IN & IN & * & * & IN & IN & \\
\hline \multirow[t]{5}{*}{ BL } & EG1 & $37.5 \pm 1.04^{a}$ & $40.2 \pm 1.13^{b}$ & $41.5 \pm 1.09^{c}$ & $42.8 \pm 1.08^{c}$ & $43.9 \pm 1.04^{d}$ & $44.4 \pm 1.05^{d}$ & * \\
\hline & EG2 & $37.1 \pm 1.04^{a}$ & $39.9 \pm 1.13^{b}$ & $41.1 \pm 1.09^{c}$ & $41.8 \pm 1.08^{c}$ & $44.0 \pm 1.04^{d}$ & $45.0 \pm 1.05^{\mathrm{e}}$ & * \\
\hline & EG3 & $37.4 \pm 1.04^{\mathrm{a}}$ & $39.2 \pm 1.13^{b}$ & $41.2 \pm 1.10^{c}$ & $43.1 \pm 1.09^{d}$ & $44.7 \pm 1.05^{\mathrm{e}}$ & $46.1 \pm 1.06^{f}$ & * \\
\hline & CG & $38.0 \pm 1.04^{\mathrm{a}}$ & $40.7 \pm 1.13^{b}$ & $42.6 \pm 1.09^{c}$ & $44.9 \pm 1.08^{d}$ & $46.2 \pm 1.04^{\mathrm{e}}$ & $46.7 \pm 1.05^{\mathrm{e}}$ & * \\
\hline & $P$ & IN & IN & IN & IN & $\mathbb{I N}$ & IN & \\
\hline \multirow[t]{5}{*}{ WH } & EG1 & $33.8 \pm 0.82^{\mathrm{a}}$ & $36.0 \pm 0.98^{b}$ & $38.7 \pm 0.90^{c}$ & $40.8 \pm 0.98^{d}$ & $42.5 \pm 1.09^{e}$ & $43.8 \pm 1.09^{f}$ & * \\
\hline & EG2 & $33.6 \pm 0.82^{a}$ & $36.7 \pm 0.98^{b}$ & $38.8 \pm 0.90^{c}$ & $40.1 \pm 0.98^{d}$ & $42.3 \pm 1.09^{e}$ & $43.9 \pm 1.09^{f}$ & * \\
\hline & EG3 & $34.4 \pm 0.82^{a}$ & $36.2 \pm 0.98^{b}$ & $39.0 \pm 0.91^{c}$ & $40.6 \pm 1.00^{d}$ & $42.5 \pm 1.11^{\mathrm{e}}$ & $43.8 \pm 1.10^{f}$ & * \\
\hline & CG & $33.9 \pm 0.82^{\mathrm{a}}$ & $36.4 \pm 0.98^{b}$ & $38.2 \pm 0.90^{c}$ & $40.6 \pm 0.98^{d}$ & $43.0 \pm 1.09^{\mathrm{e}}$ & $43.7 \pm 1.09^{\mathrm{e}}$ & * \\
\hline & $P$ & IN & IN & IN & IN & IN & IN & \\
\hline \multirow[t]{5}{*}{$\mathrm{CC}$} & EG1 & $37.8 \pm 1.19^{a}$ & $39.1 \pm 1.15^{\mathrm{b}}$ & $40.8 \pm 1.13^{c}$ & $42.8 \pm 1.11^{d}$ & $44.9 \pm 1.19^{\mathrm{e}}$ & $46.5 \pm 1.13^{\mathrm{e}}$ & * \\
\hline & EG2 & $37.3 \pm 1.19^{a}$ & $38.7 \pm 1.15^{b}$ & $40.3 \pm 1.13^{c}$ & $42.2 \pm 1.11^{d}$ & $45.0 \pm 1.19^{e}$ & $47.0 \pm 1.13^{f}$ & * \\
\hline & EG3 & $37.8 \pm 1.19^{a}$ & $38.3 \pm 1.15^{a}$ & $40.9 \pm 1.14^{b}$ & $42.6 \pm 1.12^{\mathrm{C}}$ & $45.1 \pm 1.21^{d}$ & $46.7 \pm 1.14^{d}$ & * \\
\hline & CG & $37.5 \pm 1.19^{a}$ & $40.7 \pm 1.15^{b}$ & $42.9 \pm 1.13^{\mathrm{c}}$ & $44.7 \pm 1.11^{d}$ & $45.7 \pm 1.19^{d}$ & $48.0 \pm 1.13^{\mathrm{e}}$ & * \\
\hline & $P$ & IN & IN & $\mathbb{I N}$ & IN & IN & IN & \\
\hline \multicolumn{9}{|c|}{$\mathrm{a}, \mathrm{b}, \mathrm{c}, \ldots .$. : Differences between averages with different letters on the same line were statistically significant $\left({ }^{*} \mathrm{P}<0.05\right)$. IN; insignificant } \\
\hline & & 51 & 3 & $\mathrm{nn}$ were & .05) & & & \\
\hline
\end{tabular}


There was no difference between the groups in terms of body length $(\mathrm{BL})$ averages during the study period. Within the groups, the differences were found statistically significant in terms of the BL averages in each group during the study period $(P<0.05)$. In group 1 , the means of the first, second, third, fourth and sixth measurements were different from each other, and the mean of the fifth and fourth and sixth measurements were statistically similar $(P<0.05)$. In the first 3 measurements in all groups, it was observed that the BL avarages were statistically different from each other. Only in EG3, statistically significant values were determined among all measurement averages $(P<0.05)$. According to the first $B L$ measurement values, it was seen that the EG3 had the same BL with the CG in the last measurements while the CG had the highest value(Table 1).

The differences between the first measurement average BL values and the last measurement average BL values of kids in the EG1, EG2, EG3 and CG were respectively $6.9,7.9,8.7$ and $8.7 \mathrm{~cm}$. There was no difference between EG3 and CG and it was observed that their BL increased at the same rate. In addition, between the 5th and 6th measurements, it was seen that the animals in the CG changed very little in terms of the BL and remained almost constant. However, it was seen that the increases continued at higher levels in the EG2 and EG3 who were given formula and propolis at different doses.

When the comparison between the groups was made, there was no statistically significant difference in terms of height of withers (WH ) during the study period. When the comparison within each group was made, it was seen that the difference between the measurement averages in all weeks was statistically significant $(P<0.05)$. All measurements of the CG except for the last two measurements were found to be statistically different from each other $(\mathrm{P}<0.05)$. In terms of first measurement values, it was seen that EG2 with the lowest WH. $(33.6 \mathrm{~cm})$ had the highest value $(43.9 \mathrm{~cm})$ in the last measurements. At the end of the experiment, it was observed that all three experimental groups fed with the formula had almost equal wither height with the CG that continuously sucked their mother (Table 1).

In the comparison between the groups, there was no statistically significant difference in terms of the chest circumference (CC) during the experiment $(P<0.05)$. The differences among the measurement averages of the EG1, EG2, EG3 and CG in all weeks were statistically significant $(P<0.05)$ and it was determined that the $\mathrm{CC}$ was statistically different from each other in the measurements in all weeks only in the $E G 2(P<0.05)$.

In EG1, the difference between the mean (CC) in the first five measurements was found to be statistically significant, but the difference between the averages at the 5th and 6th weeks was insignificant $(\mathrm{P}<0.05)$. In the control group, the differences between the $1 \mathrm{st}$, 2nd, 3rd, 4th and 6th week CC measurements were found to be statistically significant; however, the differences between the measurements at the 4th and 5th weeks were found to be insignificant $(P<0.05)$. At the end of the experiment, the highest $C C$ measurement with $48 \mathrm{~cm}$ was in the control group. While the EG2 was in the second row with $47 \mathrm{~cm}$, the EG3 was the third with $46.7 \mathrm{~cm}$ and EG1 was in the last row with $46.5 \mathrm{~cm}$ (Table 1).

For the mean body temperature (BT) values among the groups, the difference between the third and sixth measurement values was statistically significant $(p<0.05)$. When in-group comparisons were made, it was seen that the difference between the average body temperatures measured in all weeks in the control group was statistically insignificant. However, the in-group differences in the EGs were found to be statistically significant (P $<0.05)$.

Table 2

Least squares means and standard errors of the kids' BT $\left({ }^{\circ} \mathrm{C}\right)$

\begin{tabular}{|c|c|c|c|c|c|c|c|}
\hline & 1st day & 8th day & 15 th day & 22 th day & 29 th day & 36 th day & $\mathbf{P}$ \\
\hline EG1 & $39.53 \pm 0.09^{a b}$ & $39.47 \pm 0.09^{a b}$ & $39.54 \pm 0.06^{\mathrm{aA}}$ & $39.64 \pm 0.08^{a}$ & $39.47 \pm 0.10^{\mathrm{ab}}$ & $39.24 \pm 0.06^{\mathrm{bA}}$ & * \\
\hline EG2 & $39.78 \pm 0.09^{a}$ & $39.29 \pm 0.09^{b c}$ & $39.23 \pm 0.06^{\mathrm{bB}}$ & $39.77 \pm 0.08^{a}$ & $39.46 \pm 0.10^{a b c}$ & $39.45 \pm 0.06^{\mathrm{CAB}}$ & * \\
\hline EG3 & $39.75 \pm 0.09^{a}$ & $39.41 \pm 0.09^{b}$ & $39.29 \pm 0,07^{\mathrm{abB}}$ & $39.62 \pm 0.09^{a b}$ & $39.41 \pm 0.10^{\mathrm{ab}}$ & $39.30 \pm 0.06^{\mathrm{bA}}$ & * \\
\hline CG & $39.77 \pm 0.09^{a}$ & $39.48 \pm 0.09^{a}$ & $39.47 \pm 0.06^{\mathrm{aAB}}$ & $39.61 \pm 0.08^{a}$ & $39.54 \pm 0.10^{a}$ & $39.53 \pm 0.06^{\mathrm{aB}}$ & IN \\
\hline$P$ & IN & IN & * & $\mathbb{I N}$ & $\mathbb{I N}$ & * & \\
\hline \multicolumn{8}{|c|}{$a, b, c, \ldots .:$ Differences between averages with different letters on the same line were statistically significant $(P<0.05)$. IN; insignificant } \\
\hline$A, B, .$. & ences hotween $n$ & s with different lett & in the same column & vere statistically si & icant. $(P<0.05)$. & & \\
\hline
\end{tabular}

Glucos, Urea and hematological analysis

In the glucose levels in the blood samples collected at the beginning and at the end of the experiment, there was no statistical difference among the groups $(p<0.05)$. However, the second analysis means indicated that the difference among the groups was statistically significant $(P<0.05)$. In the evaluation between groups, the difference between EG2 and EG3was statistically insignificant in the second analysis, while the differences among EG3 and CG and EG1were found to be statistically significant (Table2). In the in-group evaluation, there was no significant difference in the CG,

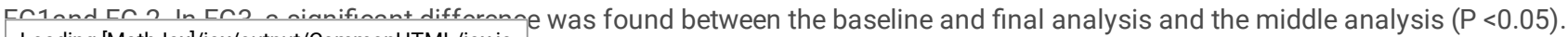

Loading [MathJax]/jax/output/CommonHTML/jax.js 
Table 3

Least squares means and standard errors of the kids' Urea(mg/DI)

\begin{tabular}{|c|c|c|c|c|c|}
\hline \multirow[t]{6}{*}{ Glucose } & & The first analysis & The second analysis & The last analysis & $P$ \\
\hline & EG1 & $115.7 \pm 3.97^{a}$ & $99.4 \pm 8.26^{\mathrm{Aa}}$ & $105.8 \pm 3.50^{\mathrm{a}}$ & IN \\
\hline & EG2 & $108.2 \pm 3.97^{a}$ & $111.8 \pm 8.26^{\mathrm{ABa}}$ & $105.8 \pm 3.50^{a}$ & $\mathrm{IN}$. \\
\hline & EG3 & $104.0 \pm 3.97^{a}$ & $142.5 \pm 8.70^{\mathrm{Bb}}$ & $113.6 \pm 3.67^{a}$ & * \\
\hline & CG & $108.8 \pm 3.97^{a}$ & $107.4 \pm 8.26^{\mathrm{Aa}}$ & $103.6 \pm 3.50^{\mathrm{a}}$ & IN \\
\hline & $P$ & IN & * & IN & \\
\hline \multirow[t]{5}{*}{ urea } & EG1 & $14.9 \pm 1.33^{a}$ & $11.2 \pm 1.15^{\mathrm{a}}$ & $14.0 \pm 1.43^{\mathrm{Aa}}$ & IN \\
\hline & EG2 & $14.4 \pm 1.33^{a}$ & $12.9 \pm 1.15^{\mathrm{a}}$ & $14.1 \pm 1.43^{\mathrm{Aa}}$ & IN \\
\hline & EG3 & $13.7 \pm 1.33^{a}$ & $11.6 \pm 1.21^{\mathrm{a}}$ & $13.1 \pm 1.51^{\mathrm{Aa}}$ & IN \\
\hline & CG & $12.8 \pm 1.33^{a}$ & $15.0 \pm 1.15^{a}$ & $20.6 \pm 1.43^{\mathrm{Bb}}$ & * \\
\hline & $P$ & IN & IN & * & \\
\hline \multicolumn{6}{|c|}{$a, b, c, \ldots$ : Differences between averages with different letters on the same line were statistically significant $(P<0.05)$. IN; insignificant } \\
\hline \multicolumn{6}{|c|}{$A, B, \ldots:$ Differences between means with different letters in the same column were statistically significant. $(P<0.05)$} \\
\hline
\end{tabular}

It was observed that there was no statistical difference among the groups in terms of mean blood urea amount obtained in the first and second blood analyzes $(p<0.05)$. However, the difference among the groups in the mean blood urea amount obtained from the last analysis was found to be insignificant for EG1, 2 and 3, and significant for the $C G(P<0.05)$. In the evaluation within the group, the difference between the three periods analysis in the $C G$ was found to be statistically significant $(P<0.05)$. 
Table 4

Least squares means and standard errors of the kids' some hematological values

\begin{tabular}{|c|c|c|c|c|c|}
\hline \multirow[t]{6}{*}{$\mathrm{RBC}(1012 / \mu \mathrm{L})$} & & The first analysis & The second analysis & The last analysis & $\mathrm{P}$ \\
\hline & EG1 & $6.31 \pm 0.332^{a}$ & $7.26 \pm 0.266^{b}$ & $8.64 \pm 0.266^{c}$ & * \\
\hline & EG2 & $6.79 \pm 0.340^{a}$ & $7.70 \pm 0.262^{b}$ & $8.63 \pm 0.262^{b}$ & * \\
\hline & EG3 & $6.33 \pm 0.340^{a}$ & $6.67 \pm 0.275^{a}$ & $8.64 \pm 0.275^{b}$ & * \\
\hline & CG & $6.98 \pm 0.332^{a}$ & $7.36 \pm 0.266^{a}$ & $8.83 \pm 0.266^{b}$ & * \\
\hline & & IN & IN & IN & \\
\hline \multirow[t]{5}{*}{ HGB $(\mathrm{g} / \mathrm{dL})$} & EG1 & $7.61 \pm 0.362^{a}$ & $8.17 \pm 0.235^{a}$ & $8.44 \pm 0.297^{a}$ & IN \\
\hline & EG2 & $8.17 \pm 0.372^{a}$ & $8.15 \pm 0.234^{a}$ & $8.36 \pm 0.295^{a}$ & IN \\
\hline & EG3 & $7.78 \pm 0.373^{a}$ & $7.77 \pm 0.240^{a}$ & $8.33 \pm 0.309^{a}$ & IN \\
\hline & CG & $8.26 \pm 0.362^{a}$ & $7.54 \pm 0.235^{b}$ & $8.23 \pm 0.297^{a b}$ & * \\
\hline & & IN & IN & IN & \\
\hline \multirow[t]{5}{*}{ HTC (\%) } & EG1 & $23.1 \pm 1.390^{a}$ & $24.1 \pm 0.924^{\mathrm{a}}$ & $24.7 \pm 0.919^{a}$ & IN \\
\hline & EG2 & $25.5 \pm 1.409^{a}$ & $24.0 \pm 0.903^{a}$ & $25.1 \pm 0.898^{a}$ & IN \\
\hline & EG3 & $24.0 \pm 1.410^{a}$ & $23.2 \pm 0.927^{a}$ & $25.1 \pm 0.942^{\mathrm{a}}$ & IN \\
\hline & CG & $26.2 \pm 1.390^{a}$ & $23.1 \pm 0.924^{b}$ & $24.6 \pm 0.919^{a b}$ & * \\
\hline & & IN & IN & IN & \\
\hline \multirow[t]{5}{*}{$\mathrm{MCH}(\mathrm{pg})$} & EG1 & $13.4 \pm 0.436^{a b}$ & $12.6 \pm 0.685^{a}$ & $14.3 \pm 0.755^{b}$ & * \\
\hline & EG2 & $13.8 \pm 0.446^{a}$ & $13.4 \pm 0.683^{a}$ & $13.5 \pm 0.753^{a}$ & IN \\
\hline & EG3 & $13.8 \pm 0.446^{a b}$ & $12.9 \pm 0.703^{a}$ & $15.2 \pm 0.789^{b}$ & * \\
\hline & CG & $13.3 \pm 0.436^{a}$ & $11.6 \pm 0.685^{b}$ & $13.9 \pm 0.755^{a}$ & * \\
\hline & & IN & IN & IN & \\
\hline \multirow[t]{5}{*}{ LYM (\%) } & EG1 & $50.3 \pm 2.83^{a}$ & $49.2 \pm 2.45^{\mathrm{a}}$ & $43.0 \pm 3.18^{a}$ & $\mathbb{I N}$ \\
\hline & EG2 & $54.4 \pm 2.93^{a}$ & $47.2 \pm 2.44^{b}$ & $44.9 \pm 3.16^{b}$ & * \\
\hline & EG3 & $49.7 \pm 2.93^{a}$ & $46.2 \pm 2.52^{\mathrm{a}}$ & $42.7 \pm 3.32^{\mathrm{a}}$ & IN \\
\hline & CG & $53.5 \pm 2.83^{a}$ & $46.9 \pm 2.45^{b}$ & $38.2 \pm 3.18^{c}$ & * \\
\hline & & IN & IN & IN & \\
\hline \multirow[t]{5}{*}{ MON (\%) } & EG1 & $3.79 \pm 1.119^{a}$ & $3.85 \pm 0.463^{a}$ & $6.00 \pm 0.948^{a}$ & IN \\
\hline & EG2 & $4.22 \pm 1.174^{\mathrm{a}}$ & $4.73 \pm 0.462^{\mathrm{a}}$ & $4.79 \pm 0.948^{a}$ & IN \\
\hline & EG3 & $5.41 \pm 1.174^{a}$ & $3.43 \pm 0.485^{a}$ & $5.94 \pm 0.996^{a}$ & IN \\
\hline & CG & $3.60 \pm 1.119^{a}$ & $3.65 \pm 0.463^{a}$ & $8.32 \pm 0.948^{b}$ & * \\
\hline & & IN & IN & IN & \\
\hline \multirow[t]{3}{*}{ GRA (\%) } & EG1 & $45.8 \pm 2.65^{a}$ & $46.9 \pm 2.46^{a}$ & $51.0 \pm 2.53^{a}$ & IN \\
\hline & EG2 & $41.6 \pm 2.74^{a}$ & $46.1 \pm 2.44^{\mathrm{ab}}$ & $50.1 \pm 2.51^{b}$ & * \\
\hline & EG3 & $44.7 \pm 2.74^{a}$ & $51.7 \pm 2.53^{b}$ & $50.3 \pm 2.63^{a b}$ & * \\
\hline
\end{tabular}




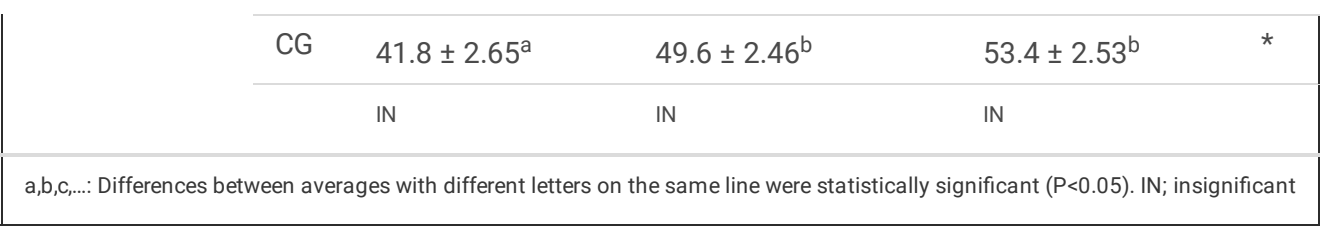

In this study, there was no statistically significant difference between the groups in terms of blood HCT rates. In the within-group evaluation, the difference between the mean HCT between the first analysis and the second analysis in the control group was found to be statistically significant $(p<0.05)$. There was a steady increase in the HTC value only in EG1. In the other groups, first a decrease and then an increase was observed (Table 4). The difference between the blood HGB $(\mathrm{g} / \mathrm{dL})$ rates among the groups was found to be statistically insignificant. In the within-group evaluation, only the difference between the mean HGB values in the first and second analysis in the CG was found to be significant ( $p<0.05)$. Also, there was a decrease in the second analysis of the control group compared to the first analysis. In other groups, this decrease was at a lower level (Table 4 ).

When each group was evaluated within itself, RBC analyzes results were found to be important in all groups. However, for the EG1, the difference among the RBC averages in blood samples taken in all three analyzes was found to be significant $(p<0.05)$. After the first analysis, there was a continuous increase in RBC averages in all groups (Table 4).

There was no significant difference among the groups in terms of $\mathrm{MCH}$ values. In the within-group evaluation, the differences among the analyzes were found to be significant in all groups except for the EG2 ( $<<0.05)$. While the values were quite stable in EG2, an increase was observed in the control group, EG3 and EG1 after the second analysis.

In terms of LYM\%, the difference among groups was found to be insignificant. In the within-group evaluation, the differences between the analyzes in the EG2 and CG in all three analysis periods were found to be statistically significant $(p<0.05)$. While the difference between the first analysis and the second and third analysis was significant in the EG2, the difference between the values in all three analyzes was significant in the CG ( $p<0.05$ ). In the second analysis, it was found that there was a greater decrease between the first and the second analysis in the CG and the EG2compared to the other groups. For the EG1, EG2, EG3 and the CG, the difference among the first analysis and the last analysis of LYM\%, was found as 7.3, 9.5, 7, 15.3, respectively. The biggest decrease was seen in the CG (Table 4).

The difference between the groups in terms of Monocyte ratios(MON\%) was statistically insignificant. However, in the within-group evaluation, the difference between the first and second analysis and the third analysis in the CG was found to be significant $(p<0.05)$. A rapid rise was observed in the last analysis of the CG (Table 4).

The difference between groups was not found to be statistically significant for Granulocyte \%(GRA) (Table 4). In the within-group evaluation, the difference between the mean values in all groups except the EG1 was found to be statistically significant $(p<0.05)$. The differences between the first and the last analysis were significant in the EG2, while the differences between the first and the second analysis in the EG3 were significant ( $p<0.05$ ). In the CG, the mean of the second and last analyzes were similar, the difference between the second and last analysis and the first analysis was found to be significant. In terms of GRA\%, between the first and second analyzes, it was observed that the EG1 remained at a value close to the first value with a slight increase, there was a slight increase in the EG2and EG3, and the highest increase was in the CG. When the final analysis values were examined, it was seen that the EG2 and EG3 were close to each other, and there was a slight decrease in the last analysis compared to the second analysis in the EG3. In all other groups there was a gradual increase among all analyzes (Table 4).

Diarrhea Scoring(DS)

On separation the kids from their mothers after the first week and on starting to give the formula with a bottle, it was observed that all three groups had kids with diarrhea every week. While diarrhea ( 1 = watery) was observed only twice in the EG1 in the first week, all diarrhea scores increased in the following weeks. Especially in the EG1 given the formula (in the 3rd week), diarrhea increased by 1, 2, 3 points, and a slight decrease was observed in all three diarrhea points in the following weeks. It was the EG1 with the highest number of diarrhea points of 1, 2, 3 Diarrhea Scores were observed 21, 19,16 times respectively in a 5-week period. Therefore, the total number of diarrhea observed in different severities in the first group was 56 . The EG1 was the highest group in terms of the total number of diarrhea observations and all three diarrhea scores (Table 5). 
Table 5

Number of Diarrhea Score(DS) observations by weeks

\begin{tabular}{|c|c|c|c|c|c|c|c|c|c|}
\hline \multirow[t]{3}{*}{ Weeks } & \multicolumn{9}{|c|}{ Number of Diarrhea Score(DS) Observations } \\
\hline & \multicolumn{3}{|l|}{ EG1 } & \multicolumn{3}{|l|}{ EG2 } & \multicolumn{3}{|l|}{ EG3 } \\
\hline & DS 1 & DS 2 & DS3 & DS 1 & DS 2 & DS3 & DS 1 & DS 2 & DS3 \\
\hline 1 & 2 & & & 2 & 2 & 3 & 5 & 2 & 3 \\
\hline 2 & 2 & 4 & 2 & 2 & & 3 & 2 & & 2 \\
\hline 3 & 9 & 8 & 3 & 3 & 3 & 6 & 1 & 8 & 5 \\
\hline 4 & 4 & 6 & 6 & 7 & 3 & 2 & & 4 & 4 \\
\hline 5 & 4 & 1 & 5 & 1 & 2 & 2 & 1 & & 1 \\
\hline Total & 21 & 19 & 16 & 15 & 10 & 16 & 9 & 14 & 15 \\
\hline
\end{tabular}

The EG2 and EG3 were the groups using the formula + propolis. In the second week in the EG2, no animals with a diarrhea score 2 were seen and the number of diarrhea was observed to decrease. In the EG2, according to 1, 2, 3 diarrhea scores were seen $15,10,16$ times respectively and totally 41 diarrhea cases were observed. In the EG3 of kids, 1, 2, 3 diarrhea points and total diarrhea frequency during the 5 weeks were $9,14,15$ and 38 times respectively. In the CG, 1 point diarrhea was observed 2 times only in the 4 th week due to the maternal effect. Discussion

During our study, the average temperature humidity index was determined between $10.58 \%$ and $16.72 \%$. According to the THI values found in our study, it was thought that there was no heat stress on animals (Marai et al. 2007).

It was an important result of the study that there was no statistically significant difference between the body weight gains of the CG during the study and the weight gains of the other three EGs fed with the formula. During the experiment, the kids started to be given $400 \mathrm{cc}$ of formula per day and it was increased to a maximum of $1100 \mathrm{cc}$ per day and gradually decreased when the kids started to eat the formula. It was suggested as a result of a study similar to this study, the goat kids was be nourished with a milk replacer by adding whey powder into cow milk instead of using the mother milk, wich could be marketed in much more profitable ways(Akcay et al. 2021).

In a study conducted by Gubicza and Molnar (1987) on calves, it was determined that 2 cc propolis supplementation caused a significant increase in live weight of calves. Supplementation of propolis during the growth period has been reported to cause an increase in calf live weight (Gubicza and Molnar 1987) and lamb live weight after weaning (itavo et al. 2011). There are too few studies on the use of propolis during the nursing period, especially on kids. In a study conducted on Nubian goats in Egypt, they reported that $0.6 \mathrm{ml}$ of propolis supplementation positively affected the body weight gain and that propolis supplement could be added to milk instead of colostrum (Sadek et al. 2020). In this study; The difference between the average live weight of kids in all groups was found to be insignificant. In some studies, it has been reported that propolis is more effective with rumen development in terms of live weight gain (Morsy et al. 2011). This study was carried out on goat kids whose rumen has not yet developed and it was observed that propolis did not affect the body weight in this period. Detection of VKP allows practical understanding of changes and sudden decreases and increases in condition that are difficult to distinguish from the outside in animals (Cobb 2005). In our study, the highest VKP value at the end was determined to be +0.4 cc propolis in the group fed with the formula.

There was no significant difference between groups in terms of body measurements. However, the groups given propolis were found to be higher than the group that only consumed formula. At the end of the study, the highest body length value belongs to the CG. The EG3 which was fed with formula $+0.2 \mathrm{cc}$ of propolis was in the second row, and the third row was the EG2, which consumes fed formula +0.4 cc of propolis In the last row, there was the EG1 that was grown only with the formula.

At the end of the experement, average body temperatures were $39.53^{\circ} \mathrm{C}$ in the $\mathrm{CG}, 39.45^{\circ} \mathrm{C}$ in the group given $\mathrm{EG} 2,39.30{ }^{\circ} \mathrm{C}$ in the group given $0.2 \mathrm{CC}$ propolis + formula, and $39.24^{\circ} \mathrm{C}$ in the group given only the formula. All measurement values were also close to literature values (Helal et al. 2010 ). We evaluated the body temperatures of the goat kids. On the 14th day, the difference between the EG1 given only formula and the EG2 and EG3 groups with propolis supplement was found to be significant $(p<0.05)$. On the 37 th day, the difference among the EG2 and the EG1 and the EG3 was found to be statistically significant $(p<0.05)$. These differences were important because changes in body temperature are an important indicator of the animals' ability to adapt to the environment, their health status and their defense mechanisms against infections. In addition, body temperature of goats changes according to the seasons (Minka and Ayo, 2016).

A significant difference was found between the group averages in terms of glucose values measured on the 15th day of the experiment. The highest glucose value was $142.5 \mathrm{mg} / \mathrm{dL}$ in the EG3 fed with $0.2 \mathrm{cc}$ propolis + the formula. It is followed by the EG2 fed with $111.8 \mathrm{mg} / \mathrm{dL}$ and $0.4 \mathrm{cc}$ propolis + the formula, respectively. It was an important result of the study that the glucose levels of the EG 2 and EG 3 were higher than the CG and the EG1 fed only the formula. Again, in the last analysis, the EG3 fed with $0.2 \mathrm{cc}$ propolis + the formula was the group with the highest glucose level.

Loading [MathJax]/jax/output/CommonHTML/jax.js 
Elitok et al. (2012) found the glucose value of $42.34 \mathrm{mg} / \mathrm{dL}$ in 1 month old Saanen goats in their study. In this study, glucose values in all groups were much higher than this value and almost twice.

Although the normal value of urea in blood in goats ranges between 4-80 mg / dL in general, the average value was given as $25 \mathrm{mg} / \mathrm{dL}$ (Mbassa and Poulsen 1991). All urea values in our study were found to be in this value range. In the first two analyzes, no difference was observed between the groups, and in the final analysis, the urea values of the formula-fed groups were found to be significantly lower than the CG values. This high urea value in the CG indicated that the kids in this group consumed too much mother milk unnecessarily. Elitok et al (2012) found the average urea value of $18.31 \mathrm{mg} / \mathrm{dL}$ in 1-month-old Saanen kids. All groups in our study are close to these values and within the specified reference range.

The altitude of the region can affect some hematological values of goat's kids. RBC and HGB ratios of Saanen goats raised in the high altitude region in Turkey were found to be higher than the RBC and HGB ratios in all groups in this study (Elitok 2012). In a study conducted in Egypt, it was observed that the HGB rates in kids who were given propolis twice a week in different doses and nanopathic form during the sucking period, varied between 13 and 23 (g/dL) (Sadek et al. 2020). In this study, it was seen that the group with the most stable HGB rates for all three analyzes was the kids in the EG2.

In this study, the difference between \% HCT rates among weeks was found to be significant only in the CG. It was determined that the progressive analysis values were lower (24.6\%) compared to the first analysis HCT (26.2\%) in the CG. This decrease was thought to be due to the kids consuming too much milk. At the end of the experiment, the highest hematocrit level (25.1\%) was found in the EG2 and EG3 who were propolis + the formula

The hematocrit value was found as $29.4 \%$ in West African Dwarf Goats (Daramola et al. 2005), 33.83\% in Saanen goats and 23.40\% in hair goats Türkyılmaz (2003). It was seen in our study that feeding kids with WHEY containing food in the early period did not cause an anemic problem. In addition, it was also an important result that the highest HTC rate was in the groups given propolis in the last analysis.

In this study, the $\mathrm{MCH}$ values obtained for all groups were found to be quite high compared to studies conducted in different breeds and in different regions. (Zumbo et al. 2011; Elitok 2012; Habibu et al. 2017).

When evaluated in general, it was important that there was a gradual decrease in LYM\% rates in all groups in this study. The decreases in group 2 given propolis and control groups were found to be statistically significant. The initial analysis LYM\% values for EG2 and control groups were 54.4 and 43.5 , respectively. In the last analysis, these values decreased to 44.9 and 38.2 , respectively (Table 4). In another study in which propolis was given in different doses and nanoparticles twice a week, it was reported that the LYM\% rates of goat's kids varied between 34 and 40 during the sucking period. In the same study, LYM\% was found to be 37 in the CG (Sadek et al., 2020). In Red Sokoto and Sahel kids, the highest and lowest LYM\% values were found as 54.36-59.54 and 59.17- 65.98, respectively, in different seasonal conditions (Habibu et al. 2017).

The first analysis monocyte mean (3.79\% and 3.60\%) of the EG1 and CG increased in the final analysis values (6\% and $8.32 \%)$. These are the two groups with the highest increase among the groups. The initial and final analysis monocyte mean values of the kids in the EG2 given 0.4 cc propolis are very close $(4.22 \%-4.79 \%)$.Monocyte ratios were found to vary between $4.66 \%$ and $5.66 \%$ for kids who were given propolis in different doses and nanoparticular form twice a week. In the same study, the monocyte value was found to be $5.0 \%$ in the CG (Sadek et al. 2020).

It has been reported in some studies that propolis increases feed utilization and has a positive effect on rumen metabolism (Öztürk et al. 2010; Morsy et al. 2011; Morsy et al. 2015). In this study, this was the period when goats could easily eat on feed when they were 35-40 days old. In this period, GRA values of the 2nd and 3rd groups given propolis were found to be lower than the other two groups (CG and EG1). In a study, it was demonstrated that different doses of propolis supplementation improved the productivity, oxidative status and immune response of Barki sheep and lambs in Egypt (Shedeed et al. 2019).

The stool score of the calf group given propolis was found to be 3, which is the most suitable and optimum score (Tolon et al. 2002). In a study in which propolis was added to the ration of piglets, it was found that diarrhea was $52 \%$ lower in the propolis group than the CG fed the same ration (Guo \& Ding, 2010). In this study, the least diarrhea score was seen in group 3 in all three groups given the formula. It was observed that morning diarrhea ceased in the evening and evening diarrhea stopped in the morning in both groups given propolis. Diarrhea was not observed for a long time in the same animal. As a result of the study, it was that propolis was effective on diarrhea. It has been observed that propolis could be used to grow kids as a preventive measure against diarrhea.

In terms of economics, the cost of one animal in the CG was 0.80 \$ per day, and $0.19 \$$ for the experimental groups. In addition, since the mothers of the kids were milked, an additional income has been provided to the business. It is known that milk yield of dairy goats peaked in the first 2 months. It is not economical to use milk in kid feeding during this period. It was determined by this study that it is much more economical to separate the kids from their mothers in the first week after taking colostrum and to feed them with a mixture containing cow's milk and Whey, In many studies on ruminants, propolis was added to food in powder form without being extracted, and positive results were obtained (Lana et al., 2007). Considering the raw price of propolis, it is not economical to use it in this way. In our study, ethanolic extract of propolis was used. The daily cost per animal was found to be $0.04 \$$.

\section{Conclusion}


According to the results of Live Weight, body measurements, body temperatures, stool scoring and blood analysis of the kids in the study, it was observed that Saanen kids grown with propolis supplement and the formula (whey+ cow milk and water) showed the same development as the kids fed with mother milk. It was concluded that it would be economical in all respects to use whey and whey powder, which is seen as waste, especially for goat rearing during and after the suction period.

Propolis and its level were effective on body temperature in kids. The Formule and different doses of Propolis had a positive effect especially on the glucose value of the boys during the nursing period. It was concluded that goats consuming propolis benefit better from energy sources. However, propolis had no effect on blood urea level.

The lower rates of $\mathrm{RBC}, \mathrm{HGB}$ and $\mathrm{HTC}, \mathrm{MCH}$, which are the red blood cells responsible for the transport of oxygen and carbon dioxide in the blood of Saanen goats, could be explained by the fact that Aydın is $52 \mathrm{~m}$ above sea level. The fact that there was no significant difference between the averages of red blood cells between the CG and The formule groups(EG1,EG2,EG3) was important in terms of showing that feeding the kids with whey foods did not cause anemic problems. In our study, on the 30th day, it was observed that the highest increase in GRA\% rates was the CG, which was breast milk suckling kids, and the EG1, which was given only formula.

The fact that the least diarrhea cases were seen in EG3 and then in the EG 2 in three groups who were raised without mother, shows that propolis could be used as a diarrhea preventive in growing kids with the formula, but further studies on the subject are recommended. The ethanolic extract of propolis is recommended to be used as a protective and supportive product as a feed additive for kids during suction and rumen development.

\section{Declarations}

\section{Acknowledgement}

The authors would like to thank to Scientific Research Projects Unit of Aydın Adnan Menderes University. This study was compiled from Selda Manav's master's thesis from the Department of Animal Science, the School of Natural and Applied Sciences Aydın Adnan Menderes University.

Author contributions: All authors contributed to the study conception and design. Material preparation and data collection were performed by all authors. Data analysis was performed by all authors. All authors read and approved the final manuscript.

Funding: Within the scope of project numbered ZRF-20015 from Scientific Research Projects Unit of Aydın Adnan Menderes University financial support was received for this study.

Compliance with ethical standards: The authors declare that the manuscript complies with the Ethical Rules applicable for Tropical Animal Health and Production journal.

Conflict of interest: The authors declare that they have no conflict of interest.

Consent to participate: Verbal informed consent was obtained from respondents prior to the interview.

Data availability statement:The datasets generated during and/or analysed during the current study are available from the corresponding author on reasonable request.

\section{References}

1. Abdolvahabi, S., Zaeemi, M., Mohri, M., Naserian, A. A. 2018. The hematological profile changes in Saanen goat kids from birth to 3 months of age. Iranian Journal of Veterinary Science and Technology, 10(1): 33-38.

2. AL-Khafaji, M.W.S. 2016. Effect of Iraqi propolis on live body weight of Awassi sheep in different age stages. Kufa Journal for Agricultural Sciences, 8 (1), 261-269.

3. Akcay, H., Yılmaz M., Kızılkaya K.,Celik K., Er, M. 2021. The use of whey powder in kids artificial rearing in environmental friendly approach. Fresenius Environmental Bulletin 30(6), 7176-7180

4. Aygun, A., Sert, D. 2013. Effects of prestorage application of propolis and storage time on eggshell microbial activity, hatchability, and chick performance in Japanese quail (Coturnix coturnix japonica) eggs. Poult Sci., 9212:3330-7.

5. Ayışığı, K., Ataşoğlu, C., Yurtman, I.Y., Mendeş, M., Pala, A. 2005. Effect of probiotic supplementation shortly before and after weaning on growth of Turkish Saanen kids. Arch, Tierz, Dummerstorf 48 (6), 601-611

6. Bonamigo, T., Campos, J. F., Oliveira, A.S., Torquato, H.F.V., Balestieri, J.B.P., Cardoso, C.A.L., Paredes-Gamero, E.J., de Picoli Souza, K., Dos Santos, E.L. 2017. Antioxidant and cytotoxic activity of propolis of plebeia droryana and apis mellifera (Hymenoptera, Apidae) from the Brazilian, Plos one 12(9). https://doi.org/10.1371/journal. pone.0183983

7. Chudoba-Drozdowska, B., Kupczyński, R., Roman, A. 2003. Application of humowitan preparation or propolis extract to calves with diarrhoea symptoms, Acta Scientiarum Polonorum-Medicina Veterinaria, 2 (2): 73-83.

Loading [MathJax]/jax/output/CommonHTML/jax.js condition scoring your ewes and ram. [http://www.livestocktrail.uiuc.adu/sheepnet/paperDisplay]. 
9. Daramola, J.O., Adeloye, A. A., Fatoba, T. A., Soladoye, A. O. 2005. Haematological and biochemival parameters of west African Dwarf goats. Livestock Research for Rular Development, 17 (8):95.

10. Denli, M., Cankaya, S., Silici, S., Okan, F., Uluocak, A.N., 2005. Effect of dietary addition of Turkish propolis on the growth performance, carcass characteristics and serum variables of quail (Coturnix coturnix japonica). Asian-Australasian Journal of Animal Sciences, 18(6): 848-854.

11. Elitok, B. 2012. Reference values for hematological and biochemical parameters in Saanen goats breeding in Afyonkarahisar province. Kocatepe Veterinary Journal, 5(1):7-11.

12. Freitas, J. A., Vanat, N., Pinheiro, J. W., Balarin, M. R. S., Sforcin, J. M., Venancio, E. J. 2011. The Effects of propolis on antibody production by laying hens. Poultry Science, 90(6): 227-1233.

13. Galina, M. A., Palma, J. M., Pacheco, D., Morales, R. 1995. Effect of goat milk, cow milk, cow milk replacer and partial substitution of the replacer mixture with whey on artificial feeding of female kids. Small Ruminant Research, 17(2): 153-158.

14. Gubicza, A., Molnar, P. 1987. Propolis in the rearing of calves 254. Magyar Mezogazdasag, 42(17): 14.

15. Guo, D. S., Ding, S. L. 2010. Effect of basal diet supplemented with propolis on production performance of weaned piglets. Animal Husbandry and Feed Science, 9: 18-19.

16. Habibu, B., Kawu, M., Makun, H., Aluwong, T., Yaqub, L., Dzenda, T., Buhari, H. 2017. Influences of breed, sex and age on seasonal changes in haematological variables of tropical goat kids. Arch. Anim. Breed., 60, 33-42.

17. Habibu, B., Kawu, M., Makun, H., Aluwong, T., Yaqub, L., Dzenda, T., \& Buhari, H. (2017). Influences of breed, sex and age on seasonal changes in haematological variables of tropical goat kids. Archiv fuer Tierzucht, 60(1): 33.

18. Harish, Z., Rubinstein, A., Golodner, M., Elmailah, M., Mizrachi, Y. 1997. Suppression of HIV-I replication by propolis and its immunoregulatory effect. Drugs Exp Clin Res., 23: 89-96.

19. Hašèík, P., Elimam, I., Garlík, J., Kacániová, M., Cuboò, J., Bobko, M., Abdulla, H. 2012. Impact of bee pollen as feed supplements on the body weight of broiler ross 308. African Journal of Biotechnology, 11: 15596-15599.

20. Helal, A., Youssef, K. M., El-Shaer, H. M., Gipson, T. A., Goetsch, A. L., Askar, A. R. 2010. Effects of acclimatization on energy expenditure by different goat genotypes. Livestock Science, 127(1): 67-75.

21. Holmøy, I.H., Waage, S. 2015. Time trends and epidemiological patterns of perinatal lamb mortality in Norway. Acta Veterinaria Scandinavica, 57: 65-76.

22. Ítavo, C. C. B. F., Morais, M. G., Costa, C., Ítavo, L. C. V., Franco, G. L., Da Silva, J. A., Reis, F. A. 2011. Addition of propolis or monensin in the diet: Behavior and productivity of lambs in feedlot. Animal Feed Science and Technology, 165(3-4): 161-166.

23. Kara, K., Güçlü, B. K., Oğuz, F. K. 2014. Use of propolis and phenolic acids in ruminant nutrition. Erciyes University Faculty of Veterinary Medicine,11(1): $43-53$ ref.74.

24. Karslı, M.A., Evci, Ş. 2018. The ımportance of cattle and calf nutrition in preventing calf losses. Lalahan Hay. Araşt. Enst. Dergi, 2018 , 58 (Özel Sayı): 23-34.(in Turkish)

25. Katircioğlu, H., Mercan, N. 2006. Antimicrobial activity and chemical compositions of Turkish propolis from different region. African Journal of Biotechnology, 5 (11): 1151-1153.

26. Kocot, J., Kiełczykowska, M., Luchowska-Kocot, D., Kurzepa, j., Musik, I. 2018. Antioxidant potential of propolis, bee pollen, and royal jelly: Possible Medical Application. Oxidative Medicine and Cellular Longevity, https://doi.org/10.1155/2018/7074209

27. Kujumgiev, A., Tsvetkova, I., Serkedjieva, Yu., Bankova, V., Christov, R., Popov, S. 1999. Antibacterial, antifungal and antiviral activity of propolis of different geographic origin. J Ethnopharmacol., 64: 235-240.

28. Kupczyński, R., Adamski, M., Falta, D., Roman, A. 2012. The efficiency of propolis in post-colostral dairy calves. Arch Tierz, 55: $315-324$.

29. Littell, R. C., Milliken, G. A., Stroup, W. W., Wolfinger, R. D. 1997. SAS system for mixed models. SAS Institute Inc Cary NC.

30. Marai, I.F.M., Abou-Fandoud, E.I., Daader, A.H., AbuElla, A.A., 2002. Reproductive doe traits of the Nubian (Zaraibi) goats in Egypt. Small Rumin. Res., 46: 201-205.

31. Marai, I.F.M., El-Darawany, A.A., Fadiel, A., Abdel-Hafez, M.A.M. 2007. Physiological traits as affected by heat stress-a review. Small Ruminant Res., 71: $1-12$.

32. Mbassa, G.K., Poulsen, J.S. 1991. Influence of pregnancy, lactation and environment on some clinical chemical reference values in Danish landrace dairy goats (Capra hircus) of different parity-II. Plasma urea, creatinine, bilirubin, cholesterol, glucose and total serum proteins. Comparative Biochemistry Physiology Part B, Comparative Biochemistry 100: 423-431.

33. Minka, N S and Ayo, J O 2016 Effects of Cold-Dry (Harmattan) and Hot-dry seasons on daily rhythms of rectal and body surface temperatures in sheep and goats in a natural tropical environment. Journal of Circadian Rhythms, 14(1): 8, pp. 1-11, DOI: http://dx.doi.org/10.5334/jcr.143

34. Morsy, A. S., Soltan, Y. A., Elzaiat, H. M., Sallam, S. M. A., Alencar, S. M., Helder, L., Abdalla, A. L. 2011. Effect of two types of Brazilian propolis extracts on rumen gas and methane production and truly degradability in vitro. Middle East. North African Journal of Animal Science, 4: $446-456$.

35. Morsy, A. S., Soltan, Y. A., Sallam, S. M. A., Kreuzer, M., Alencar, S. M., Abdalla, A. L. 2015. Comparison of the in vitro efficiency of supplementary bee propolis extracts of different origin in enhancing the ruminal degradability of organic matter and mitigating the formation of methane. Animal Loading [MathJax]/jax/output/CommonHTML/jax.js 60. 
36. Murad, J.M., Calvi, S.A., Soares, A.M.V.C., Bankova, V., Sforcin, J.M. 2002. Effect of propolis from Brazil and Bulgaria on fungucidal activity of Macrophages against Paracoccidioides Brasiliensis. J. Ethnopharmacol., 79: 331-334.

37. Onur, E., Nalbantsoy, A., Kışla, D. 2018. Immunotherapy and potential use of propolis ın cancer immunotherapy. Food and Health, 4(4): 231-246 • DOI: 10.3153/FH18023.(in Turkish)

38. Öztürk, H., Pekcan, M., Sıreli, M., Fidanç, U.R. 2010. "Effects of Propolis on in Vitro Rumen Microbial Fermentation. Ankara Univ Vet Fak Derg., 57 (4): 217-221.

39. Pinheiro, J., Douglas, B., Saikat D. R., Deepayan S. and the R Development Core Team (2013). nlme: Linear and nonlinear mixed effects models. R package version 3.1-108.

40. Russell, A. J. F., Doney, J. M., Gunn, R. G. 1969. Subjective assessment of body fat in live sheep. J. Agric. Sci., 72: $451-454$.

41. Sadek, W. M. A., El-Houssiny, A. S., Al-Mwafy, A., Farag, T. K., Al-Gethami, A., Grawish, S. I. M., Hegazi, A. G. 2020. Egyptian propolis 16: The effect of consumption of propolis and alginate-propolis nanoparticles in combination with colostrum on the performance of newborn goats. Adv. Anim. Vet. Sci, 8(12): 1256-1265.

42. Shedeed, H.A., Farrag, B., Elwakeel, E.A., Abd El-Hamid, I.S., El-Rayes, M.A. 2019. Propolis supplementation improved productivity, oxidative status, and immune response of Barki ewes and lambs. Veterinary World, 12(6): 834-843.

43. Silici, S. 2015. Propolis üzerine ön klinik araştırmalar(Pre-clinical studies on propolis). Erciyes Üniversitesi Fen Bilimleri Dergisi, 31(3): 185-191.(in Turkish)

44. Tekeli, A., Kutlu, H.R., Celik, L. 2011. Effects of Z. Officinale and propolis extracts on the performance, carcass and some blood parameters of broiler chicks. Current Research in Poultry Science. 1 (1): 12-23.

45. Tolon, B., Önenç, A., Kaya, A., Altan, Ö. 2002. Effects of propolis on growth of calves.1st German Congress for Bee Products and Apitherapy. 23-24 March, Passau-Germany.P.71.

46. Türkyılmaz, B. 2003. Sannen Irkı Keçiler ve kıl keçilerinde eritrosit içi potasyum ve glutatyon tiplerinin karşıllaştırılması. Uludağ Üniversitesi Sağlık Bilimleri Enstitüsü Yüksek Lisans Tezi, (Basılmamış), Bursa. .(in Turkish)

47. Ünal, H. B., Taşkın, T., Kandemir, Ç. 2018. Küçükbaş hayvancılıkta yavru ölümlerinin azaltılmasına yönelik barındırma ve yetiştirme uygulamaları(Housing and husbandry practices to reduce mortality rate of offspring in small ruminant production). J. Anim. Prod., 59 (2): $55-63$. (in Turkish)

48. Ünlü, H.B., Erkek, R., Özdoğan, M., Mert, S. 2013. "Buzağı beslemede doğal yem katkı maddelerinin kullanımı", J. Anim. Prod 54(2), 36-42. (in Turkish)

49. Velikova, M., Bankova, V., Sorkun, K., Houcine, S., Tsvetkova, I., Kujumgiev, A. 2000. Propolis from the Mediterranean region: chemical composition and antimicrobial activity. Z Naturforsch [C]., 55(9-10): 790-793.

50. Yang, M. S. J. 2010. Propolis and illite as feed additives on performance and blood profiles of pre-weaning Hanwoo calves. Journal of Animal and Veterinary Advances, 9(19): 2526-2531.

51. Zeedan, K. I. I., Komonna, O. F. 2013. Improvement of immunological and productive performance for buffaloes by using some natural additive. 1Effect of propolis as feed additive on productive and reproductive performance. Egyptian Journal of Nutrition and Feeds, $16(2$ (Special Issue)): 35-54.

52. Zeng, Z., Zhang, S., Wang, H., Piao, X. 2015. Essential Oil and Aromatic Plants as Feed Additives in Non-Ruminant Nutrition: a Review. Journal of Animal Science and Biotechnology, 6(7): 2-10.

53. Zumbo, A., Sciano, S., Messina, V., Casella, S., di Rosa, A. R., Piccione, G. 2011. Haematological profile of messinese goat kids and their dams during the first month post-partum. Animal Science Papers \& Reports, 29(3):223-230. 